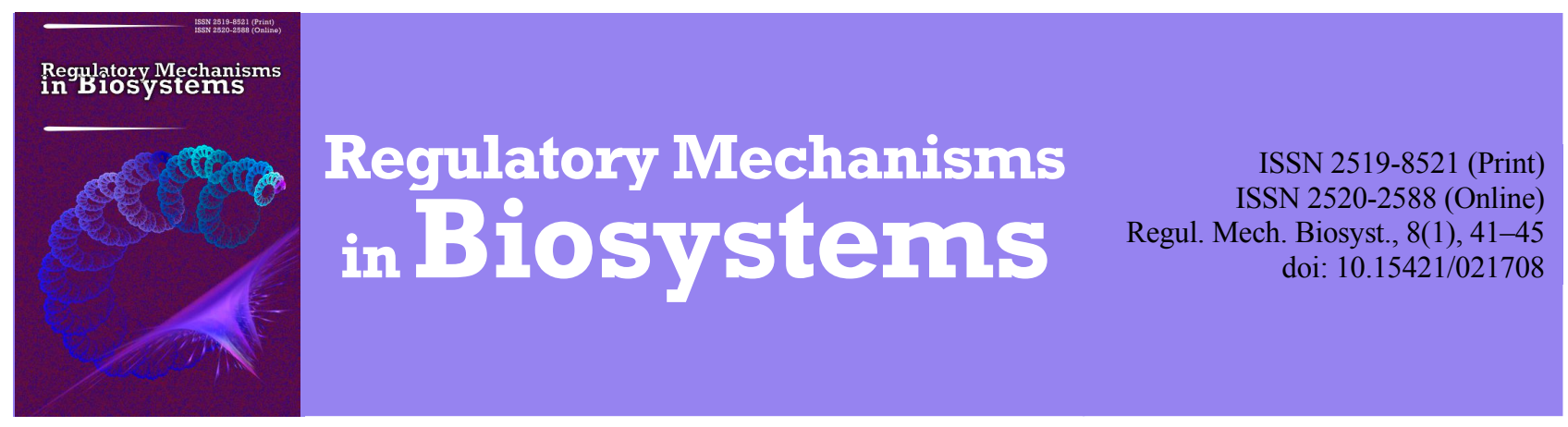

\title{
Research on acute and chronic toxity of the experimental drug Amprolinsyl
}

\author{
B. Gutyj, I. Khariv, V. Binkevych, O. Binkevych, N. Levkivska, D. Levkivskyj, Y. Vavrysevich \\ Lviv National University of Veterinary Medicine and Biotechnologies named after S. Z. Gzhytskyj, Lviv, Ukraine
}

Article info

Received 08.01.2017

Received in revised form 30.01.2017

Accepted 05.02.2017

Lviv National University of Veterinary Medicine and Biotechnologies named after S. Z. Gzhytskyj, Pekarska Str., 50 , Lviv, 79010, Ukraine Tel. $+38-068-136-20-54$ E-mail:bvh@ukr.net

Gutyj, B., Khariv, I., Binkevych, V., Binkevych, O., Levkivska, N., Levkivskyj, D., \& Vavrysevich, Y. (2017). Research on acute and chronic toxity of the experimental drug Amprolinsyl. Regulatory Mechanisms in Biosystems, 8(1), 41-45. doi: $10.15421 / 021708$

The drug Amprolinsyl is a is a mixture of hydrochloric amprolium (12.5 g) and milled fruits of the milk thistle (up to $100 \mathrm{~g}$ ), designed to prevent and treat protozoonoses in birds, especially when mixed associative invasions occur. The fruits of the milk thistle contain the natural vitamins (A, C, E, B) and the minerals (copper, iron, cobalt) and other factors that significantly expand and enhance the pharmacological effect of the drug Amprolinsyl. We found that when the drug Amprolinsyl was administered intra gastrically to white rats at a dose of $5000 \mathrm{mg} / \mathrm{kg}$ and higher clinical signs of toxicity occurred after 4-5 hours. Damage to motor activity and tremors of individual muscles of these animals was observed. The rats died after 1-4 days. A direct relationship was found between the drug at a specific dosage and the death of rats. After intra gastric administration of the drug Amprolinsyl to white rats clinical signs of toxicity appeared after 5-6 hours at a dose of $4000 \mathrm{mg} / \mathrm{kg}$ body weight. These animals attempted to gather in groups and to hide in the bedding. The death of the mice occured in 1-3 days. Thus, $\mathrm{LD}_{50}$ drug of Amprolinsyl following intra gastric administration to white rats was 5,917 and for white mice $5,167 \mathrm{mg} / \mathrm{kg}$. After studying the cumulative properties of Amprolinsyl, it was found that the total drug administered in average doses was $831 \mathrm{mg} / \mathrm{kg}$, and the cumulative rate 8.31. Long-term daily intragastric administration of Amprolinsyl over 24 days affected the functional state of the liver and kidneys. The magnitude of weight ratios of lungs, heart and spleen during the research period was the same as in the control group of rats. Significant changes were found only after analyzing the leukocyte profile. A reduction was observed in the number of neutrophils to $54.7 \%$ and an increase in the number of lymphocytes to $9.2 \%$. Following prolonged daily administration of increasing doses Amprolinsyl causes a slight degradation of the membranes of hepatocytes, which indicates increased activity of aminotransferases. When investigating the chronic toxicity of Amprolinsyl it was found that at doses of $1 / 50 \mathrm{LD}_{50}$, and $1 / 100 \mathrm{LD}_{50}$ the drug had no effect on the results of functional tests, due to the normal functioning of the liver tissue and the lack of negative impact on animals in the $3 \mathrm{rd}$ and 4 th groups. Administration of the the drug at doses of 1/20, 1/50 and 1/100 $\mathrm{LD}_{50}$ over 30 days did not significantly affect the functional state of the internal organs of the experimental animals. When investigating the morphological blood parameters of the rats following oral administration of Amprolinsyl at different doses a downward trend in the haemoglobin and colour index value and a likely reduction in the number of white blood cells, compared to the control group was observed in all experimental groups. According to the values of haematological and biochemical parameters, it was established that in spite of the low toxicityof Amprolinsyl at doses of 1/20 and 1/50 LD 50 the drug had an effect on lipid metabolism, as was shown following the increase of glycerol.

Keywords: pharmacology; accumulation; toxicity; amprolium; milk thistle; rats; mice; turkeys

\section{Introduction}

In our previous studies (Khariv, 2010) we found that in treating coccidiosis and histomoniasis in turkeys Brovitacoccid with total use of milk thistle fruits showed a high level of therapeutic efficiency. Brovitacoccid is a $12.5 \%$ premix containing: $12.5 \mathrm{~g}$ of hydrochloric amprolium, vitamin A - 1 million IU, Vitamin K $200 \mathrm{mg}$, corn flour up to $100 \mathrm{~g}$. Amprolium is an anticoccidiosis preparation of benzimidazole (Gibbon et al., 2016). In the bodies of Eimeria amprolium blocks the metabolism of glucose-6-phosphate dehydrogenase, which leads to disorders in the carbohydrate metabolism and death of the parasites (Joyner, 1970; McDougald and Galloway, 1973; Chapman, 1982; McDougald and Seibert, 1998; Nweze and Obiwulu, 2009). In the small intestine where Eimeria parasites are located, epithelial cells of the mucosa are destroyed. This leads to catarrhal inflammation, Eimeria toxins delay blood clotting, so in the complex preparation Brovitakcoccid vitamin $\mathrm{K}$ is present, which acts as a haemocoagulant and generates vitamin A, which activates the regeneration of the epithelium of the mucous membranes. Several experimental studies have found that the protozoan infestations suppress the immune system, resulting in the development of secondary immunodeficiency in animals and birds. In these animals, protozoan infestation was complicated with viral and bacterial microflora (McLoughlin, 1970; Chapman, 1976; Platzer et al., 2005; Rosadio et al., 2010; Bangoura et al., 2014; Chapman and Jeffers, 2014). In our studies of healthy turkeys it was found that Brovitacoccid even at a therapeutic dose ( $2 \mathrm{~g} / \mathrm{kg}$ feed $)$ suppressed the immune system of birds. Given the above immunosuppressive effect of Brovitacoccid, we have developed a method of treatment for turkeys using Brovitacoccid together with the fruits of the milk thistle $-2 \mathrm{~g} / \mathrm{kg}$ feed of both drugs over 5 days. The high therapeutic efficiency of milk thistle fruit is engendered by the flavinoid group "silymarin" (Khariv and Gutyj, 2016; Khariv et al., 2016; Martyshuk et al., 2016). This blocks excessive lipid 
peroxidation and protects cell membranes from aggressive forms of oxygen. All this ensures the strong hepatoprotective and antioxidant actionof the drug.

Another essential component of milk thistle fruit is the wide range and high level of its vitamins. In particular, vitamin C (ascorbic acid) activates the synthesis of antibodies - immunoglobulin classes IgA and IgM. Vitamin C enhances the activity component, enhances immune function and increases the nonspecific interferon parts of the immune defense of the body against bacterial infections (Gutyj et al., 2016; Lavryshyn et al., 2016; Smolynets et al., 2016). Vitamin K, which is part of the thistle, ensures stable blood clotting, and provides the minerals copper, iron and cobalt which are involved in erythropoiesis. Vitamins $\mathrm{A}$ and $\mathrm{E}$ provide quick regeneration of the intestinal epithelium affected by Eimeria (Khariv, 2010).

As a result of detailed study of the pharmacodynamics of Brovitacoccid and fruits of milk thistle in the treatment of birds affected with Eimeria and histomonads, we have developed the drug Amprolinsyl. This product contains amprolium - an antiEimeria agent and silymarin - an antioxidant, hepatoprotective and immunostimulation agent. Amprolinsyl is intended for the prevention and treatment of protozoonoses in birds, especially mixed associative invasions. For prevention, it should be administered at $1 \mathrm{~g} / \mathrm{kg}$ of feed, for therapeutic use at $2 \mathrm{~g} / \mathrm{kg}$ of feed. Like Brovitacoccid, Amprolinsyl contains hydrochloric amprolium with antiprotozoan action. Instead of synthetic vitamins $A$ and $C$, the drug Amprolinisyl contains ground fruits of the milk thistle containing natural vitamins (A, C, E, B) and minerals (copper, iron, cobalt etc.), which greatly expand and enhance its pharmacological effect. In accordance with the guidelines of the pre-clinical study of drugs, every new drug must be examined for the following indicators: determination of the toxicity of the Amprolinsyl bioassay to infusoria; establishment of the toxicity of Amprolinsyl in laboratory animals after a single administration (acute toxicity); exploration of the cumulative properties of the drug on white rats; investigation of the toxicity of Amprolinsyl in laboratory animals after long-term administration (chronic toxicity) in order to study the efficiency of Amprolinsyl. The study was conducted in accordance with the recommendations "Toxicological control of new means of protecting animals" and "Preclinical studies of veterinary medicines".

The aim of research was:

1) to determine the toxicity of Amprolinsyl with laboratory animals after a single administration ("acute toxicity");

2) to investigate the cumulative properties of the drug with white rats;

3) to establish the toxicity of Amprolinsyl with laboratory animals when it was administered over a long period (chronic toxicity).

\section{Materials and methods}

Setting the acute toxicity of the drug. Experiments to study the acute toxicity of Amprolinsyl were performed on 30 white rats, 2-3-months of age, weighing 170-190 g and 30 white mice, 2-3months of age, weighing 19-22 g. The drug was injected once into the empty stomachs of the test animals using a metal probe. The experiment was conducted on 5 groups of animals, each consisting of 6 animals. The drug was administered to laboratory animals in the following doses: white rats 4,000, 5,000, 6,000, 7,000, $8,000 \mathrm{mg} / \mathrm{kg}$ active ingredient (a. i.) and white mice $-3,000,4,000$, $5,000,6,000,7,000 \mathrm{mg} / \mathrm{kg}$ (a. i.). The studies of acute toxicity of Amprolinsyl for young turkeys were performed on birds 25 days old, weighing $1,000-1,200 \mathrm{~g}$. The drug was administered into the goiter of the research turkeys at doses of 5,25 and $50 \mathrm{~g} / \mathrm{kg}$ of body weight of birds. The high dose was administered in small installments at intervals of 2-3 hours. Following administration of the drug, monitoring observation of the laboratory animals and poultry lasted for 14 days. On the first day of the experiment the animals were under constant surveillance. Then we took into account the following indicators: general condition, appearance, behaviour of the animals, intensity and nature of the mobile activity, presence of convulsions, coordination, response to external stimuli (tactile, sound, light), the condition of the hair, visible mucous membranes, reaction to the food, rhythm, respiratory rate, time of occurrence and nature of intoxication, its severity, course, the death or recovery of the animals. During the experiment attention was paid to the loss of laboratory animals and, depending on the action of the drug at particular dosages the average dose $\left(\mathrm{LD}_{50}\right)$ of the dosage form was calculated by the method of G. Koerber.

$\mathrm{LD}_{50}$ was calculated using the formula:

$$
\mathrm{LD}_{50}=\mathrm{LD}_{100}=-\Sigma(\mathrm{zd}) / \mathrm{m},
$$

where $\mathrm{DL}_{100}$ - the dose that killed all the animals, $\Sigma-$ the symbol of sum, $\mathrm{z}$ - half the total number of animals that died from the effects of the researched drug in the following two doses, $\mathrm{d}$ - difference of two subsequent doses, $\mathrm{m}$ - the number of animals in the group at each dose.

The study of cumulative properties. Properties on the drug accumulation were studied with 12 white rats weighing 140-150 g. The rats were divided into two groups: control and experimental. To determine the degree of accumulation of the drug we used method of K. S. Lima et al. (1961). The drug was injected into the experimental animals, daily on an empty stomach, once intragastrically using a metal probe for laboratory rats. The drug was administered in large doses every day in small portions at intervals of 2 to 4 hours between doses. The experiment lasted for 24 days. Amprolinsyl was administered to rats at doses ranging from $0.1 \mathrm{LD}_{50}$, the dose being increased by 1.5 times every 4 days. At the end of the experiment the dose of Amprolinsyl was $0.50-0.75 \mathrm{LD}_{50}$. During the experiment the general condition and death rate of rats was assessed. Depending on the dose, the cumulative rate was calculated according to the formula proposed by Kahan and Stankevych (1964):

$$
\mathrm{K}_{\text {cum }}=\mathrm{LD}_{50} \mathrm{n} / \mathrm{LD}_{50} 1
$$

where $\mathrm{K}_{\text {cum }}$ is cumulation coefficient, $\mathrm{DL}_{50} \mathrm{n}$ and $\mathrm{DL}_{50} \mathrm{l}-$ mortal middle dose for multiple and single injection, respectively. To identify the impact of the drug in the above dosage on the body at the end of the experiment, at the end of the next day after the final administration of Amprolinsyl the animals from each group were weighed and then decapitated under conditions of mild ether anesthesia and their blood samples were taken for haematological and biochemical studies. After dissection of the animals', the internal organs were extracted and weighed, and the ratios of weight compared to the control group were calculated.

Study of toxicity Amprolinsyl in chronic experiment. In the study of chronic toxicity we were guided by the results obtained in the course of acute toxicity. The drug was administered daily by intramuscular injection. During the experiment we monitored the clinical condition and behaviour of the animals.

Chronic toxicity was studied with 40 white rats weighing 90 $110 \mathrm{~g}$. They were formed into 4 groups of 10 rats equal in number and weight. The first (I) group was the control animals' group. They were injected with isotonic sodium chloride solution. Animals from other three groups were administered Amprolinsyl at the following doses: Group II $-1 / 20 \mathrm{LD}_{50}$, Group III $-1 / 50 \mathrm{LD}_{50}$ and Group IV - 1/100 LD ${ }_{50}$. In the chronic experiment Amprolinsyl was administered to rats for 30 days.

On 31st day from the start of administration, the detoxification of liver function was measured for 5 rats from each group using hexenal tests (Rozin, 1964). For this, the laboratory animals were injected intraperitoneally with $1 \%$ solution of hexenal at a dose of $45 \mathrm{mg} / \mathrm{kg}$. Then we recorded the average sleep time from the moment when the animal took the side position.

At the same time, the other 5 rats were subjected to the M. L. Rylova swimming test. For this experiment, a glass aquarium was used. The column of water in the tank was $50 \mathrm{~cm}$. Water temperature $-12-13{ }^{\circ} \mathrm{C}$. The experimental animals were weighted with objects (metal batch) $-5 \%$ of body weight. Before the experiment, the rats were weighed and the abovementioned weight load was attached to their tails. Then both experimental and control animals of about the same weight were placed into the tank. We then made a constant observation of the animals swimming. The indicator of efficiency was how long the animals could survive in the water. 
The animals swam until they sank to the bottom without resurfacing. On the next day, the laboratory animals were decapitated under light ether anesthesia, and haematological and biochemical investigations made using the commonly recognized methods and their body mass as compared to the control group established.

Mathematical processing of the research results was statistically worked out using the software package Statistica 6.0. The average values of the data were considered statistically significant at $\mathrm{P}<$ 0.05 (ANOVA)

\section{Results}

Setting the acute toxicity of the drug. We found that intragastric administration of the drug Amprolinsyl to white rats, at a dose of $5,000 \mathrm{mg} / \mathrm{kg}$ and higher caused onset of clinical signs of intoxication after 4-5 hours, which was marked by poor coordination of movements and tremor of individual muscles. The death of the animals took place within 1-4 days. The number of dead animals was in direct proportion to the dose of the drug. The research data and calculations $\mathrm{LD}_{50}$ drug are presented in Table 1 .

\section{Table 1}

Averege lethal dose of Amprolinsyl for white rats

following intra gastric administration

after calculation by G. Kerber method

\begin{tabular}{|c|c|c|c|c|c|c|c|}
\hline Drug, $\mathrm{mg} / \mathrm{kg}$ & 4000 & 5000 & & 6000 & & 7000 & 8000 \\
\hline survivors & 6 & 4 & & 3 & & 1 & 0 \\
\hline dead & 0 & 2 & & 3 & & 5 & 6 \\
\hline Z & 1.0 & & 2.5 & & 3.5 & & 5.5 \\
\hline d & 1000 & & 1000 & & 1000 & & 1000 \\
\hline $\mathrm{zd}$ & 1000 & & 2500 & & 3500 & & 5500 \\
\hline
\end{tabular}

$\mathrm{DL}_{50}=8000-[(1000+2500+3500+5500): 6]=5916,7 \mathrm{mg} / \mathrm{kg}$.

So, $\mathrm{LD}_{50}$ of the drug Amprolinsyl for intra gastric administration of white rats is $5,917 \mathrm{mg} / \mathrm{kg}$. After intragastric introduction to white mice, it was found that the drug Amprolinsyl at a dose of $4,000 \mathrm{mg} / \mathrm{kg}$ and higher brought clinical signs of toxicity after 5-6 hours, and was marked by poor coordination of movements and tremor individual muscles. The animals stayed together in a group and tried to hide in the bedding. The deaths of the mice occurred over 1-3 days in direct proportion to the particular dosage of the drug (Table 2).

Table 2

Average lethal dose of Amprolinsyl for white mice following intra gastric administration after calculation by G. Kerber method

\begin{tabular}{|c|c|c|c|c|c|c|}
\hline Drug, mg/kg & 3000 & 4000 & & 5000 & 6000 & 7000 \\
\hline survivors & 6 & 5 & & 3 & 2 & 0 \\
\hline dead & 0 & 1 & & 3 & 4 & 6 \\
\hline Z & & 0.5 & 2.0 & 3.5 & 5.0 & \\
\hline $\mathrm{d}$ & & 1000 & 1000 & 1000 & 1000 & \\
\hline $\mathrm{zd}$ & & 500 & 2000 & 3500 & 5000 & \\
\hline
\end{tabular}

$\mathrm{LD}_{50}=7000-[(500+2000+3500+5000): 6]=5166,7 \mathrm{mg} / \mathrm{kg}$.

So, $\mathrm{LD}_{50}$ drug of Amprolinsyl after intragastric administration to white mice is $5,167 \mathrm{mg} / \mathrm{kg}$. Introduction of drug to turkeys in doses of 5,25 and $50 \mathrm{~g} / \mathrm{kg}$ body weight did not cause the death of the birds during the period of the experiment. After administration of the drug at a dose of $50 \mathrm{~g} / \mathrm{kg}$ the turkeys experienced a sharp depression, refusal to feed and lost their response to stimuli. On the following day, the state of birds is greatly improved, and by the 3 4th day changes in the clinical condition of the experimental animals compared with the control group were not registered. $\mathrm{LD}_{50}$ for internal intragastric introduction to laboratory animals of Amprolinsyl (white mice and rats) is $5,000 \mathrm{mg} / \mathrm{kg}$.

The study of cumulative properties. Study was conducted on the properties of cumulative doses of Amprolinsyl following the death of the experimental animals. The total introduction of the drug in high doses was $831.25 \mathrm{mg} / \mathrm{kg}$ and the maximum accumulation was under 8.31 , indicating mild to cumulative properties of the drug. We set reduction coefficients of liver weight to $5.0 \%$ and right kidney by $5.2 \%$ after long-term oral administration of Amprolinsyl to rats in increasing doses (Table 3).

The magnitude of weight ratios of lungs, heart and spleen for the research period was the same as in the control group of rats. Thus, prolonged daily intragastric administration of Amprolinsyl over 24 days affected the functional state of the liver and kidneys. After study of the morphological parameters of rats' blood after oral administration of Amprolinsyl in increasing doses, we established that the main parameters of the blood of the research group were the same as in the rats in the control group (Table 4).

Significant changes were found only after analyzing the leukocyte profile. We found a probable decrease, as compared with the control group, in the number of neutrophils by $54.7 \%$ and increase by $9.2 \%$ in the number of lymphocytes. It was established that longterm administration of the drug at increasing doses significantly influenced some biochemical parameters of the experimental animals (Table 5). Thus, ALT activity significantly increased compared to rats in the control group to $14.6 \%$, and alkaline phosphatase - decreased by $39.9 \%$. We found a significant increase in serum compared with the control group, the level of glycerol to $46.1 \%$ of total lipids by $27.9 \%$ and total cholesterol - by $21.6 \%$, which points to increased lipid metabolism in the body of the experimental rats. Thus, Amprolinsyl, when provided over a long period (24 days) in daily admini. stration of increasing doses causes a slight degradation of the membranes of hepatocytes, which indicates increased activity of the intracellular enzyme ALT.

\section{Table 3}

Factors of internal organ mass of white rats in studying the cumulative properties of Amprolinsyl $(M \pm m, n=12)$

\begin{tabular}{lrc}
\hline \multicolumn{1}{c}{ Internal organs } & \multicolumn{1}{c}{ Control } & After the $24^{\text {th }}$ day \\
\hline Lungs & $8.9 \pm 0.50$ & $8.1 \pm 0.87$ \\
Liver & $41.5 \pm 2.15$ & $39.4 \pm 1.00$ \\
Right kidney & $3.8 \pm 0.17$ & $3.6 \pm 0.08$ \\
Left kidney & $3.6 \pm 0.22$ & $3.4 \pm 0.11$ \\
Heart & $3.7 \pm 0.17$ & $3.62 \pm 0.11$ \\
Spleen & $5.5 \pm 0.70$ & $5.0 \pm 0.24$ \\
\hline
\end{tabular}

Table 4

The morphological parameters of blood of white rats at the 24 th day of the experiment studying the cumulative properties of Amprolinsyl $(\mathrm{M} \pm \mathrm{m}, \mathrm{n}=12)$

\begin{tabular}{lrc}
\hline \multirow{2}{*}{ Indices } & \multicolumn{2}{c}{ Group } \\
\cline { 2 - 3 } & \multicolumn{1}{c}{ control } & \multicolumn{1}{c}{ the $24^{\text {th }}$ day } \\
\hline Hemoglobin, g/l & $116.8 \pm 6.29$ & $117.5 \pm 3.68$ \\
Red blood cells, T/L & $7.7 \pm 0.70$ & $8.56 \pm 0.78$ \\
Hematocrit, \% & $36.7 \pm 0.01$ & $40.0 \pm 1.29$ \\
Colour indicator & $0.47 \pm 0.04$ & $0.42 \pm 0.03$ \\
The average content of hemoglobin, pg & $31.8 \pm 1.15$ & $29.7 \pm 0.37$ \\
The average volume of red blood cells, mkm ${ }^{3}$ & $49.8 \pm 4.56$ & $40.0 \pm 1.29$ \\
White blood cells, D/L & $10.0 \pm 1.19$ & $11.8 \pm 3.52$ \\
Eosinophils, \% & $0.01 \pm 0.001$ & $0.01 \pm 0.001$ \\
Neutrophils, \% & $15.0 \pm 1.83$ & $6.8 \pm 0.80^{*}$ \\
Lymphocytes, \% & $83.5 \pm 1.66$ & $91.2 \pm 1,46^{*}$ \\
Monocytes, \% & $1.8 \pm 0.37$ & $2.5 \pm 0.86$ \\
\hline
\end{tabular}

\section{Table 5}

Biochemical parameters of blood of white rats at the end of the experiment to determine the cumulative properties of Amprolinsyl $(\mathrm{M} \pm \mathrm{m}, \mathrm{n}=12)$

\begin{tabular}{lll}
\hline \multirow{2}{*}{ Indices } & \multicolumn{2}{c}{ Animals' group } \\
\cline { 2 - 3 } & \multicolumn{1}{c}{ control } & The $24^{\text {th }}$ day \\
\hline Total protein, g/l & $8.40 \pm 0.25$ & $7.40 \pm 0.39$ \\
ALT, mkkat/l & $0.41 \pm 0.04$ & $0.47 \pm 0.01^{*}$ \\
AST, mkkat/l & $0.66 \pm 0.04$ & $0.70 \pm 0.03$ \\
LF, mkkat/l & $1.48 \pm 0.07$ & $0.89 \pm 0.06^{*}$ \\
Glycerol, mmol/L & $1.02 \pm 0.11$ & $1.49 \pm 0.12^{*}$ \\
Lipids general, g/l & $2.19 \pm 0.15$ & $2.80 \pm 0.14^{*}$ \\
Cholesterol general, mmol/L & $5.65 \pm 0.58$ & $6.87 \pm 0.45^{*}$ \\
Cholesterol free, $\mathrm{mmol} / \mathrm{L}$ & $2.12 \pm 0.13$ & $2.09 \pm 0.11$ \\
Glucose, mg/l & $4.97 \pm 0.12$ & $5.52 \pm 0.52$ \\
\hline
\end{tabular}


Study of toxicity of Amprolinsyl in chronic experiment. After conducting experiments to study the chronic toxicity the death of rats was not registered. On the 30th day of the experiment, after the introduction of the drug in doses $1 / 20,1 / 50$ and $1 / 100 \mathrm{LD}_{50}$, probable variation of the mass of internal organs compared with the control group was not shown (Table 6).

A statistically significant $(\mathrm{P}<0.05)$ increase in the average sleep time and decrease in the average swimming time $(\mathrm{P}<0.05)$ was found in two groups of animals. These changes indicate damage to detoxification of liver function in the context of overall depressing effect on the body caused by long-term administration of the drug at a dose $1 / 20 \mathrm{LD}_{50}$. The drug doses $1 / 50$ and $1 / 100 \mathrm{LD}_{50}$ had no effect on the results of functional tests, due to the normal functioning of the liver tissue and the lack of negative impact on animals of the 3rd and 4th groups. On the 30th day of the experiment, after the introduction of the drug at doses 1/20, 1/50 and $1 / 100 \mathrm{LD}_{50}$ probable variation of the mass of internal organs compared with the control group was not shown (Table 7).

Thus, the drug Amprolinsyl after administration at doses 1/20, $1 / 50$ and $1 / 100 \mathrm{LD}_{50}$ over 30 days did not significantly affect the functional state of the internal organs of the experimental animals. After researching morphological blood parameters in rats after oral administration of Amprolinsyl at different doses, we established a downward trend in hemoglobin and colour index value and a likely reduction in the number of white blood cells, compared with the control group, in all experimental groups (Table 8).

Table 6

Results of functional tests $(\mathrm{M} \pm \mathrm{m}, \mathrm{n}=20)$

\begin{tabular}{cccc}
\hline $\begin{array}{c}\text { Animal's } \\
\text { group }\end{array}$ & $\begin{array}{c}\text { Drug } \\
\text { in a dose }\end{array}$ & $\begin{array}{c}\text { Hexenal test, average } \\
\text { sleeping time, min }\end{array}$ & $\begin{array}{c}\text { Swimming test, average } \\
\text { swimming time, min }\end{array}$ \\
\hline 1 & control & $28.8 \pm 1.66$ & $12.8 \pm 1.51$ \\
2 & $1 / 20 \mathrm{LD}_{50}$ & $35.8 \pm 1.67^{*}$ & $9.1 \pm 1.37^{*}$ \\
3 & $1 / 50 \mathrm{LD}_{50}$ & $31.1 \pm 0.66$ & $11.3 \pm 1.89$ \\
4 & $1 / 100 \mathrm{LD}_{50}$ & $29.9 \pm 1.89$ & $13.0 \pm 1.59$ \\
\hline
\end{tabular}

So, after the introduction of Amprolinsyl at a dose of $1 / 20 \mathrm{LD}_{50}$ the leukocyte count decreased by $35.1 \%$, and at doses $1 / 50 \mathrm{LD}_{50}$, and $1 / 100 \mathrm{LD}_{50}$ by $34.7 \%$ and $39.3 \%$ respectively. In the fourth group after using Amprolinsyl at a dose $1 / 100 \mathrm{LD}_{50}$ we found a likely increase in the number of red blood cells, and tendency to increase in the average content of hemoglobin, resulting in colour index value which was significantly lower compared with the control group, by $19.2 \%$. An analysis of the leukocyte profile showed a probable 3-6 fold increase in the number of eosinophils in all experimental groups compared with the control group.

Table 7

Factors mass of internal organs of white rats on the 30th day of the study of chronic toxicity of Amprolinsyl $(M \pm m, n=6)$

\begin{tabular}{|c|c|c|c|c|}
\hline \multirow{2}{*}{ Internal bodies } & \multicolumn{4}{|c|}{ Animal group } \\
\hline & control & $1 / 20 \mathrm{LD}_{50}$ & $1 / 50 \mathrm{LD}_{50}$ & $1 / 100 \mathrm{LD}_{50}$ \\
\hline Lungs & $8.8 \pm 0.54$ & $8.5 \pm 0.54$ & $7.7 \pm 0.63$ & $7.7 \pm 0.22$ \\
\hline Liver & $41.5 \pm 2.14$ & $41.5 \pm 2.16$ & $43.5 \pm 2.02$ & $40.2 \pm 0.78$ \\
\hline Right kidney & $3.8 \pm 0.17$ & $3.6 \pm 0.16$ & $3.7 \pm 0.08$ & $3.4 \pm 0.05$ \\
\hline Left kidney & $3.6 \pm 0.22$ & $3.7 \pm 0.18$ & $3.6 \pm 0.88$ & $3.3 \pm 0.87$ \\
\hline Heart & $3.7 \pm 0.17$ & $3.9 \pm 0.26$ & $3.7 \pm 0.16$ & $3.6 \pm 0.19$ \\
\hline Spleen & $5.5 \pm 0.70$ & $5.8 \pm 0.39$ & $6.7 \pm 0.22$ & $4.8 \pm 0.19$ \\
\hline
\end{tabular}

Table 8

The morphological parameters of white rats' blood on the 15 th day of the experiment studying the chronic toxicity of Amprolinsyl $(M \pm m, n=24)$

\begin{tabular}{|c|c|c|c|c|}
\hline \multirow{2}{*}{ Indicess } & \multicolumn{4}{|c|}{ Animal group } \\
\hline & control & $1 / 20 \mathrm{LD}_{50}$ & $1 / 50 \mathrm{LD}_{50}$ & $1 / 100 \mathrm{LD}_{50}$ \\
\hline Hemoglobin, g/l & $116.8 \pm 6.29$ & $104.2 \pm 7.98$ & $108.3 \pm 8.47$ & $114.3 \pm 6.89$ \\
\hline Red blood cells, T/L & $7.7 \pm 0.70$ & $7.5 \pm 0.49$ & $8.0 \pm 0.6$ & $9.2 \pm 0.94 *$ \\
\hline Hematocrit, \% & $37.7 \pm 1.28$ & $32.2 \pm 1.93$ & $33.0 \pm 1.78$ & $33.3 \pm 1.65$ \\
\hline Colour indicator & $0.47 \pm 0.04$ & $0.41 \pm 0.01$ & $0.42 \pm 0.05$ & $0.38 \pm 0.04 *$ \\
\hline The average content of hemoglobin, pg & $31.8 \pm 1.15$ & $32.3 \pm 1.63$ & $33.5 \pm 2.99$ & $38.9 \pm 3.53$ \\
\hline The average volume of red blood cells, $\mathrm{mkm}^{3}$ & $49.8 \pm 4.56$ & $43.6 \pm 2.32$ & $41.7 \pm 2.43$ & $37.4 \pm 4.43$ \\
\hline White blood cells, D/L & $10.01 \pm 1.19$ & $6.50 \pm 1.12 *$ & $6.54 \pm 0.68^{*}$ & $6.08 \pm 1.12 *$ \\
\hline Eosinophils, \% & $0.2 \pm 0.01$ & $0.66 \pm 0.06^{*}$ & $0.67 \pm 0.03 *$ & $0.33 \pm 0.03 *$ \\
\hline Neutrophils, \% & $15.0 \pm 1.83$ & $11.83 \pm 1.97$ & $12.8 \pm 3.02$ & $11.75 \pm 2.39$ \\
\hline Lymphocytes, \% & $83.0 \pm 1.66$ & $85.5 \pm 2.4$ & $84.6 \pm 2.82$ & $86.0 \pm 2.7$ \\
\hline Monocytes, \% & $1.8 \pm 0.37$ & $2.4 \pm 0.37$ & $1.67 \pm 0.67$ & $2.0 \pm 0.71$ \\
\hline
\end{tabular}

Table 9

Biochemical parameters of white rats' blood on the 30 th day of the experiment studying the chronic toxicity of Amprolinsyl $(M \pm m, n=24)$

\begin{tabular}{|c|c|c|c|c|}
\hline \multirow{2}{*}{ Indices } & \multicolumn{4}{|c|}{ Animal group } \\
\hline & control & $1 / 20 \mathrm{LD}_{50}$ & $1 / 50 \mathrm{LD}_{50}$ & $1 / 100 \mathrm{LD}_{50}$ \\
\hline Total protein, $\mathrm{g} / \mathrm{l}$ & $8.4 \pm 0.25$ & $8.8 \pm 0,78$ & $9.0 \pm 0,29$ & $9.7 \pm 0,47^{*}$ \\
\hline $\mathrm{ALT}, \mathrm{mkkat} / \mathrm{l}$ & $0.41 \pm 0.04$ & $0.35 \pm 0.03$ & $0.42 \pm 0.02$ & $0.43 \pm 0.03$ \\
\hline AST, mkkat/1 & $0.66 \pm 0.04$ & $0.74 \pm 0.02$ & $0.76 \pm 0.02$ & $0.80 \pm 0.12$ \\
\hline $\mathrm{LF}, \mathrm{mkkat} / \mathrm{l}$ & $1.48 \pm 0.07$ & $1.47 \pm 0.05$ & $1.52 \pm 0.03$ & $1.60 \pm 0.16$ \\
\hline Glycerol, mmol/L & $1.0 \pm 0.11$ & $1.6 \pm 0.33$ & $1.1 \pm 0.08$ & $1.4 \pm 0.10$ \\
\hline Lipids general, g/1 & $2.19 \pm 0.15$ & $3.35 \pm 0.26^{* *}$ & $2.7 \pm 0.15^{*}$ & $2.6 \pm 0.13$ \\
\hline Cholesterol general, $\mathrm{mmol} / \mathrm{L}$ & $5.65 \pm 0.58$ & $5.11 \pm 0.58$ & $5.23 \pm 0.26$ & $5.54 \pm 0.42$ \\
\hline Cholesterol free, $\mathrm{mmol} / \mathrm{L}$ & $2.12 \pm 0.13$ & $2.02 \pm 0.07$ & $1.95 \pm 0.07$ & $2.12 \pm 0.06$ \\
\hline Glucose, $\mathrm{mg} / \mathrm{l}$ & $4.97 \pm 0.12$ & $4.83 \pm 0.14$ & $4.85 \pm 0.28$ & $4.29 \pm 0.19 *$ \\
\hline
\end{tabular}

After administration of Amprolinsyl at doses of $1 / 20$ and $1 / 50$ $\mathrm{LD}_{50}$ the rats' serum level was quite high, glycerol - by $52.9 \%$ and $23.3 \%$ higher than in the control group of rats. Significant changes of total and free cholesterol in the blood serum of the experimental animals was registered (Table 9). Rats which were administered the drug at a dose $1 / 100 \mathrm{LD}_{50}$ had total protein level that increased by $15.5 \%$ while glucose was significantly lower by $13.7 \%$ compared to the rats in the control group. So, after studying the action of Amprolinsyl at toxic doses in a chronic experiment, the values of haematological and biochemical parameters revealed that, despite the low toxicity, Amprolinsyl at doses of $1 / 20$ and $1 / 50 \mathrm{LD}_{50}$ affects lipid metabolism indicating an increase in glycerol. Amprolinsyl at doses higher than therapeutic, affects the hematopoietic function (reducing the number of white blood cells in all experimental groups). 


\section{Discussion}

Considering the pathogenesis of Eimeria and Histomnas invasion, the treatment of poultry should be causal and pathogenetic. For etiotropic treatment it is necessary to free the body of the bird from parasites. Among the wide range of anti-Eimeria drugs available today, the most effective is Brovitacoccid of domestic production (McLoughlin, 1970; Chapman, 1976; Khariv, 2010; Rosadio et al., 2010; Gibbons et al., 2016). During the second phase of treatment it is necessary to use medicines that activate the hematopoietic function of bone marrow, restore liver function, stabilize the state of the cell membranes of hepatocytes and enhance cellular, humoral and nonspecific parts of the immune system. In the range of immunostimulatory and hepatoprotective drugs a prominent position is occupied by herbs which are used for treating a variety of diseases caused by the weakening of endogenous antioxidant defence, secondary immunodeficiency and related disorders in homeostasis (Gutyj et al., 2016; Martyshuk et al., 2016; Smolynets et al., 2016). Based on reports in the literature and our own researches on healthy turkeys and those affected by Eimeria and Histomonas invasion, we found that among the most effective hepatoprotectors the fruits of milk thistle merit special attention. They contain flavonoids - silicristin, silidianin, silibilin, united under the title "Silymarin" (Khariv, 2010; Gutyj et al., 2016). Flavonoids act hepatoprotectively, stabilize the state of cell membranes and activate proteinsynthesis liver function. It should be noted that in the fruit of milk thistle there is a wide range of vitamins $(\mathrm{A}, \mathrm{E}, \mathrm{K}, \mathrm{C}, \mathrm{B})$, macro $(\mathrm{K}, \mathrm{Ca}, \mathrm{Mg})$, micronutrients $(\mathrm{Cu}, \mathrm{Co}, \mathrm{Fe}, \mathrm{J}, \mathrm{Si})$, and essential and inessential amino acids involved in metabolism and erythropoiesis, stimulating the formation of antibodies and raising immune health (Khariv et al., 2016; Martyshuk et al., 2016).

\section{Conclusions}

This study of the acute toxicity of the antiprotozoan drug Amprolinsyl, which has been recently developed in Ukraine, using laboratory animals concerns a drug of low toxicity (the 4th grade of toxicity State ST 12.1.007-76). Long-term daily intragastric administration of Amprolinsyl during 24 days affects the functional state of the liver and kidneys. We studied of morphological parameters of the blood of rats by oral administration of Amprolinsyl in increasing doses, and established that the main parameters of blood in the research group were the same as in the control group of rats, significant changes were found only after analyzing the leukocyte profile. We established that there was a probable decrease as compared with the control group, in the number of neutrophils by $54.7 \%$ and increase by $9.2 \%$ in the number of lymphocytes. Amprolinsyl, under long-term (24 days) daily administration of increasing doses causes a slight degradation of the membranes of hepatocytes, which indicates increased activity of the intracellular enzyme ALT.

Amprolinsyl at doses $1 / 50$ and $1 / 100 \mathrm{LD}_{50}$ had no effect on the results of functional tests, due to the normal functioning of the liver tissue and the lack of negative impact on animals in the 3rd and 4th groups. Amprolinsyl after administration at doses 1/20, 1/50 and $1 / 100 \mathrm{LD}_{50}$ over 30 days did not significantly affect the functional state of the internal organs of the experimental animals.

The study of the morphological parameters of rats' blood following oral administration of Amprolinsyl at different doses established a downward trend in hemoglobin values and the colour indicator and a probable reduction in the number of white blood cells in all experimental groups compared with the control group.

According to hematological and biochemical parameters we revealled that, despite the low toxicity of Amprolinsyl at doses of $1 / 20$ and $1 / 50 \mathrm{LD}_{50}$ the drug affects lipid metabolism, which indicates increase in glycerol.

\section{References}

Bangoura, B., Alnassan, A. A., Lendner, M., Shehata, A. A., Krüger, M., \& Daugschies, A. (2014). Efficacy of an anticoccidial live vaccine in prevention of necrotic enteritis in chickens. Experimental Parasitology, $145,125-134$

Chapman, H. D. (1976). Studies on the mode of action of anticoccidial drugs in the chicken and chicken embryo. Veterinary Parasitology, 1(4), 299-308.

Chapman, H. D. (1982). The treatment of coccidiosis: Studies on the sensitivity of recent field isolates of Eimeria acervulina type to anticoccidial drugs given in the drinking water. Journal of Comparative Pathology, 92(2), 213-218.

Chapman, H. D., \& Jeffers, T. K. (2014). Vaccination of chickens against coccidiosis ameliorates drug resistance in commercial poultry production. International Journal for Parasitology: Drugs and Drug Resistance, 4(3), 214-217.

Gibbons, P., Love, D., Craig, T., \& Budke, C. (2016). Efficacy of treatment of elevated coccidial oocyst counts in goats using amprolium versus ponazuril. Veterinary Parasitology, 218, $1-4$.

Gutyj, B. V., Hufriy, D. F., Hunchak, V. M., Khariv, I. I., Levkivska, N. D., \& Huberuk, V. O. (2016). The influence of metisevit and metifen on the intensity of lipid per oxidation in the blood of bulls on nitrate load. Scientific Messenger LNUVMBT named after S.Z. Gzhytskyj. 18(3), 67-70.

Gutyj, B. V., Murs'ka, S. D., Gufrij, D. F., Hariv, I. I., Levkivs'ka, N. D., Nazaruk, N. V., Gajdjuk, M. B., Pryjma, O. B., Bilyk, O. J., \& Guta, Z.A. (2016). Influence of cadmium loading on the state of the antioxidant system in the organism of bulls. Visnyk of Dnipropetrovsk University. Biology, Ecology, 24(1), 96-102.

Gutyj, B., Lavryshyn, Y., Binkevych, V., Binkevych, O., Paladischuk, O., Strons'kyj, J., \& Hariv, I. (2016). Influence of Metisevit on the activity of enzyme and nonenzyme link of antioxidant protection under the bull's body cadmium loading. Scientific Messenger LNUVMBT named after S.Z. Gzhytskyj, 18(2), 52-58.

Gutyj, B., Paska, M., Levkivska, N., Pelenyo, R., Nazaruk, N., \& Guta, Z. (2016). Study of acute and chronic toxicity of 'injectable mevesel' investigational drug. Biological Bulletin of Bogdan Chmelnitskiy Melitopol State Pedagogical University, 6(2), 174-180.

Joyner, L. P. (1970). Coccidiosis: Problems arising from the development of anticoccidial drug resistance. Experimental Parasitology, 28(1), 122-128.

Khariv, I. I. (2010). The influence of milk thistle on the performance of nonspecific resistance of the turkey organism. Scientific Messenger LNUVMBT named after S. Z. Gzhytskyj, 13(3), 292-296.

Khariv, M., Gutyj, B., Butsyak, V., \& Khariv, I. (2016). Hematological indices of rat organisms under conditions of oxidative stress and liposomal preparation action. Biological Bulletin of Bogdan Chmelnitskiy Melitopol State Pedagogical University, 6(1), 276-289.

Khariv, M. I., \& Gutyj, B. V. (2016). Influence of the liposomal preparation Butaintervite on protein synthesis function in the livers of rats under the influence of carbon tetrachloride poisoning. Visnyk of Dnipropetrovsk University. Biology, Medicine, 7(2), 123-126.

Lavryshyn, Y. Y., Varkholyak, I. S., Martyschuk, T. V., Guta, Z. A., Ivankiv, L. B., Paladischuk, O. R., Murska, S. D., Gutyj, B. V., \& Gufriy, D. F. (2016). The biological significance of the antioxidant defense system of animals body. Scientific Messenger LNUVMBT named after S. Z. Gzhytskyj, 18(2), 100-111.

Martyshuk, T. V., Gutyj, B. V., \& Vishchur, O. I. (2016). Level of lipid peroxidation products in the blood of rats under the influence of oxidative stress and under the action of liposomal preparation of Butaselmevit. Biological Bulletin of Bogdan Chmelnitskiy Melitopol State Pedagogical University, 6(2), 22-27.

McDougald, L. R., \& Galloway, R. B. (1973). Eimeria tenella: Anticoccidial drug activity in cell cultures. Experimental Parasitology, 34(2), 189-196.

McDougald, L. R., \& Seibert, B. P. (1998). Residual activity of anticoccidial drugs in chickens after withdrawal of medicated feeds. Veterinary Parasitology, 74(2-4), 91-99.

McLoughlin, D. K. (1970). Coccidiosis: Experimental analysis of drug resistance. Experimental Parasitology, 28(1), 129-136.

Nweze, N. E., \& Obiwulu, I. S. (2009). Anticoccidial effects of Ageratum conyzoides. Journal of Ethnopharmacology, 122(1), 6-9.

Platzer, B., Prosl, H., Cieslicki, M., \& Joachim, A. (2005). Epidemiology of Eimeria infections in an Austrian milking sheep flock and control with diclazuril. Veterinary Parasitology, 129, 1-9.

Rosadio, R., Londoñe, P., Pérez, D., Castillo, H., Véliz, A., Llanco, L., Yaya, K., \& Maturrano, L. (2010). Eimeria macusaniensis associated lesions in neonate alpacas dying from enterotoxemia. Veterinary Parasitology, 168, 116-120.

Rozin, D. G. (1964). Modern evaluation of toxicity chlorproductive carbohydrates of fatty raw yder gexanal test with white mice. Pharmacology and Toxicology, 5, 613-614.

Smolynets', I. B., Gutyj, B. V., Khariv, I. I., Petryshak, O. Y., \& Lytvyn, R. I. (2016). Pharmaceutical marketing: Objectives and types. Scientific Messenger LNUVMBT named after S.Z. Gzhytskyj, 18(2), 151-154. 